\title{
EXTRACTION OF AGGLUTININS FROM Arthrospira platensis BIOMASS IN THREE DIFFERENT BUFFERS
}

\author{
LIMA, K. L ${ }^{1}$, NASCIMENTO, C. O ${ }^{1}$, COSTA, R. M. P. B ${ }^{1}$, A. L. F. PORTO ${ }^{1}$, BEZERRA, R. P \\ ${ }^{1}$ and VIANA MARQUES, D. $\mathrm{A}^{1}$ \\ ${ }^{1}$ Universidade Federal Rural de Pernambuco, Departamento de Morfologia e Fisiologia Animal \\ E-mail para contato: daniela_viana@yahoo.com.br
}

\begin{abstract}
Arthrospira platensis contains large amounts of proteins, vitamins, lipids and pigments with various biological functions, such as antitumor, antiviral, antimicrobial activities. The aim of this work was detected the presence of agglutinins in Arthrospira platensis biomass extracted in three different buffers. The harvested cells were concentrated by a centrifugation at 4,000 $x \mathrm{~g}$ for $10 \mathrm{~min}$, lyophilized and extracted under sonication in pure and in concentrations of $1: 5$ to $1: 20$ of $0.025 \mathrm{M}$ Tris-HCl-saline, $\mathrm{pH} 7.0 ; 0.02 \mathrm{M}$ salinephosphate, $\mathrm{pH} 7.4$; and $0.1 \mathrm{M}$ sodium acetate, $\mathrm{pH}, 5.5$ buffers. For hemagglutination activity tests, in microtiter boards, extracts were added to rabbit erythrocytes. Positive results were obtained for hemagglutination activity only in saline-phosphate buffer $(1: 5,1: 10$, and 1:20 dilutions) and sodium acetate buffer (1:5, and 1:10 dilutions) with titers of $2^{12}$ and $2^{7}$, respectively. These organisms would be potential sources of novel agglutinins for biomedical research.
\end{abstract}

\section{INTRODUCTION}

Cyanobacteria are prokaryotes that perform oxygenic photosynthesis and constitute a large taxonomic group within the domain of Eubacteria. Cyanobacteria are divided morphologically (unicellular or filamentous) or functionally $\left(\mathrm{N}_{2}\right.$-fixing and non- $\mathrm{N}_{2}$-fixing). Filamentous species are subdivided into those with and without a heterocyst which is a differentiation from vegetative cells for fixing nitrogen (DESIKACHAR, 1973; DOOLITTLE, 1982). Arthrospira is a representative filamentous non- $\mathrm{N}_{2^{-}}$fixing cyanobacterium that lacks any differentiation such as for the heterocyst, akinete or hormogonium, which develops in some filamentous $\mathrm{N}_{2}$-fixing cyanobacteria. This genus is also well known as 'Spirulina' because of its useful property as a food. The Aztecs consumed it regularly (VAN TUERENHOUT, 2005).

Historically, the classification of Arthrospira and Spirulina genera was a subject of controversy. For the commercial strain, Arthrospira or Spirulina was used interchangeably. Both Arthrospira and Spirulina are similar in morphological characters, such as: cylindrical, multicellular, filamentous cyanobacteria with an open, left-handed and helical shape. They both belong to the Phylum Cyanobacteria, Order Oscillatoriales and Family Oscillatoriaceae. (CASTENHOLZ, 2001) However, those organisms can be differentiated by the presence of cell septa: Arthrospira possess septa, whereas Spirulina do not (TOMASELLI et al., 1996). 
Arthrospira platensis shows vigorous gliding motility of filamentous cells (trichome) with rotation along their long axis. Gliding is a self-propulsion across a solid or semisolid material without the aid of any visible flagellum (HOICZYK, 2000) and it has become an important industrial organic material as a health supplement, a source of $\beta$-carotene and a natural colouring agent. The presence of hydrogenases in its cells also makes this cyanobacterium a useful material for clean energy production (LOSEVA and DARDYNSKAYA, 1993; AMAO and NAKAMURA, 2006).

Several studies have shown significant interest in finding compounds that have biological activities from microalgae biomass, one of applications of bioactive extracted by natural products is the hemagglutinating activity. Haemagglutinin are proteins with characteristics of binding to specific carbohydrate. These biomolecules are abundant in nature, are important for cell aggregation and glycoconjugates and consequently have a high relevance to biomedical and pharmaceutical research. Seaweed (macroalgae) hemagglutinins have the ability to agglutinate erythrocytes treated enzymatically preferably of rabbits and other animals. Several studies reported that hemagglutinin algae have immunomodulatory and antitumor activities in vitro e in vivo (LIMA et al., 1998; NEVES et al., 2001). This study aims to determine the best extraction method of possible hemagglutinins biomolecules using three different buffers through sonication to establish the hemagglutination activity of the extracts of Arthrospira platensis.

\section{MATERIALS AND METHODS}

\subsection{Microalgae and media}

Arthrospira platensis (UTEX 1926) was obtained from the UTEX (University of Texas, Austin). Cultures were maintained axenically in broth culture medium described by SCHLÖSSER (1982), composed (g/L): $\mathrm{NaHCO}_{3}, 13.61 ; \mathrm{Na}_{2} \mathrm{CO}_{3}, 4.03 ; \mathrm{K}_{2} \mathrm{HPO}_{4}, 0.50 ; \mathrm{NaNO}_{3}$ 2.50; $\mathrm{K}_{2} \mathrm{SO}_{4}, 1.00 ; \mathrm{NaCl}, 1.00 ; \mathrm{MgSO}_{4} .7 \mathrm{H}_{2} \mathrm{O}, 0.20 ; \mathrm{CaCl}_{2} .2 \mathrm{H}_{2} \mathrm{O}, 0.04$; mineral solution, $6 \mathrm{~mL}$ and vitamin $\mathrm{B} 12$, which was suggested by University of Texas Culture Collection. The culture medium was sterilized in an autoclave at $121^{\circ} \mathrm{C}$ for $20 \mathrm{~min}$.

\subsection{Culture conditions}

Arthrospira platensis was grown autotrophically on $100 \mathrm{~mL}$ of sterile culture media (initial $\mathrm{pH}$ of 6.8 ) in $250-\mathrm{mL}$ Erlenmeyer flasks at $28 \pm 2{ }^{\circ} \mathrm{C}$, under a constant fluorescent light intensity of approximately $74 \mu \mathrm{mol}$ photons $\mathrm{m}^{-2} \mathrm{~s}^{-1}$ measured by a LI-250 Light Meter with a LI-190 quantum sensor (LI-COR, USA). Agitation during cell growth was provided by shaker (TECNAL BRAND, MODEL TE-1004). Initial cell concentration was $50 \mathrm{mg} \mathrm{L}^{-1}$ for all the cultivation conditions. Each $24 \mathrm{~h}$ samples were taken from the flasks to determine the cell density.

\subsection{Determination of cell dry weight and optical density}


Cell concentration (optical density) was estimated by absorbance of the suspension at 560 nm (LEDUY and THERIEN, 1977) with a UV-vis spectrophotometer. A calibration curve between optical density and cell dry weight was developed by filtering the aliquots on preweighed GF/C filter paper. The filtered cells were dried at $105{ }^{\circ} \mathrm{C}$ until constant weight was obtained and cooled to room temperature in desiccators before weighing. Subsequently, the culture was centrifuged at $10,000 \mathrm{rpm}$ for $20 \mathrm{~min}$ at $4^{\circ} \mathrm{C}$ and the dry biomass used in the compounds extraction step.

\section{$2.4 \mathrm{pH}$ determination}

The $\mathrm{pH}$ was measured using a potentiometer (METTLER TOLEDO M300).

\subsection{Microalgae biomass extracts preparation}

Biomass extracts were prepared as described in Chu et al. (2006), Dinh et al. (2009) and Roman Bermejo et al. (2001) methodologies. In the first step, the cells were suspended in $200 \mathrm{ml}$ of TBS buffer (Tris- $\mathrm{HCl}$ - saline) of $\mathrm{pH} 7.4$ and containing $25 \mathrm{mM} \mathrm{NaCl}$ at $4{ }^{\circ} \mathrm{C}$. In the second, samples was carried out with 2 volumes of $0.02 \mathrm{M}$ phosphate buffer, $\mathrm{pH} 7.0$ containing $0.85 \%$ $\mathrm{NaCl}$ (saline - PBS) at $4{ }^{\circ} \mathrm{C}$. In the third step, the suspension was frozen in $1 \mathrm{M}$ sodium acetate (pH 5.5) buffer. In three cases, the microalgae biomass extracts were placed under sonication in ice bath by 10 cycles of 10 minutes. Aliquots were removed and centrifuged at 5,000 rpm $7 \mathrm{~min}$, $4^{\circ} \mathrm{C}$, using the supernatant for hemagglutinating activity with dilutions of 1:5, 1:10 and 1:20.

\subsection{Determination of hemagglutinating activity (HA)}

The determination of hemagglutinating activity (HA) in the supernatants was performed in microtiter plates, following the method described by Correia and Coelho et al. (1995). Extracts preparation $(50 \mu \mathrm{L})$ was two-fold serially diluted with $0.15 \mathrm{M} \mathrm{NaCl}$. After that the addition of a 50 $\mu \mathrm{L}$ suspension of rabbit erythrocytes treated with $2.5 \%(\mathrm{v} / \mathrm{v})$ glutaraldehyde was realized. After resting for $45 \mathrm{~min}$, HA was expressed as the highest dilution exhibiting hemagglutination. Hemagglutination was observed macroscopically and judged as positive in the case that more than $50 \%$ of erythrocytes in the well were agglutinated. Hemagglutination activity was expressed as a titer and the reciprocal of the highest two-fold dilution exhibited positive hemagglutination. The assay was carried out in triplicate for each test solution.

\section{RESULTS AND DISCUSSION}

Table 1 shows the results of hemagglutinating activity of Arthrospira platensis biomass extracted in different buffers using sonication method. Negative hemagglutinating activity was observed in the biomass extraction by Tris-HCl-saline buffer. However, faster positive results were obtained in sodium phosphate buffer (1:10 and 1:20 dilutions) and sodium acetate buffer (1:5 and 1:10 dilutions) with high hemagglutination titers of $2^{12}(4,096)$ in the first buffer.

Many studies have been reported the ability of agglutination of macroalgae extracts (Chu et al., 2006; Fábregas et al. (1984,1985) ; Munoz et al., 1985). Phosphate buffer gained prominence in our research, for being the best buffer show hemagglutinating activity to extract from the cyanobacterium Arthrospira platensis using sonication method. This data corroborated studies by 
LE DINH et al. (2009) that used the same buffer to extract agglutinins of several species of macroalgae with the range of hemagglutination between $2^{2}$ and $2^{6}$.

Table 1. Hemagglutinating activity of Arthrospira platensis biomass extracted in different buffers (sodium phosphate, sodium acetate and Tris-HCl saline)

\begin{tabular}{lcc} 
Buffer type & Extracts dilutions & Hemagglutinating activity \\
\hline Sodium phosphate & $1: 10,1: 20$ & $2^{2} \mathrm{a} 2^{12}$ \\
Sodium acetate & $1: 5,1: 10$ & $2^{2} \mathrm{a} 2^{7}$ \\
Tris- $\mathrm{HCl}$ saline & Pure extract $1: 5$, & Negative \\
& $1: 10$, and $1: 20$ &
\end{tabular}

In 1981, Hori et al. used human ABO system, erythrocytes of rabbit, horse, sheep, duck and chicken and others and found hemagglutinating activity in 14 of the 53 species tested, and the authors also observed that rabbit erythrocytes are the best suited to agglutinate compounds from algae biomass for prove more sensitive to the action of hemagglutinin present in these organisms. Similarly, FÁBREGAS et al. (1984,1985) and MUNOZ et al. (1985) working with green and red algae collected from Spain coast, observed that $100 \%$ of the tested algae were able to agglutinate rabbit erythrocytes and the agglutination was quite poor when used erythrocyte ABO system. SAMPAIO et al. 1993 also showed some algae the ability to agglutinate erythrocytes of rabbit preferentially. For these reasons, erythrocytes of these animals were used in our hemagglutination tests.

\section{CONCLUSION}

We conclude that both buffers tested were suitable for biomolecules extraction with higher hemagglutinating power against rabbit erythrocytes, highlighting the phosphate buffer as the best. Maybe, this buffer presents a $\mathrm{pH}$ near to neutral, and prevents the denaturation or conformational changes of biomolecules, mainly for proteins. Thus, A. platensis can be recognized as a potential source of new bioactive compounds of interest for biotechnological applications in the fields of human and veterinary medicine because of the possible presence of a non-immunological protein compound that binds to the blood, thus confirming the potential of these biomolecules in future studies for diagnostic medicine.

\section{REFERENCES}

AMAO, Y. and NAKAMURA, N. 2006, Biohydrogen production with the light-harvesting function of grana 
CASTENHOLZ, R.W. 2001. Oxygenic photosynthetic bacteria. In: Boone D.R. and Castenholz R.W. (eds), Bergey's Manual of Systematic Bacteriology (2nd ed.), Volume 1, Springer-Verlag, New York, pp. 473-600.Congress of Applied Algology, Czech Republic.

CHU, C.Y.; HUANG, R.; LIN, L.P. Purification and characterization of a novel haemagglutinin from Chlorella pyrenoidosa.Journal of Industrial Microbiology and Biotechnology, v. 33, p. 967-973, 2006.

CORREIA M.T.S., COELHO L.C.B.B. Purification of a glucose/mannose specific lectin, isoform 1, from seeds of Cratylia mollis mart (Camaratu Bean), Appl Biochem Biotech. 55 (1995) 261-273.

DESIKACHARY, T.V. 1973, In: Carr, N.G. and Whitton, B.A. (eds.), Botanical Monographs, Blackwell Scientific. Publications: Oxford, London, Edinburgh, Melbourne, pp. $473-81$

DINH, H. L.; HORI, K.; QUANG, N. H. Screening and preliminary characterization of hemagglutinins in Vietnamese marine algae. Journal Applied of Phycology, v. 21, p. 89-97, 2009.

DOOLITTLE, W.F. 1982, In: Carr, N.G. and Whitton, B.A. (eds.), The Biology of Cyanobacteria, Botanical from Spirulina and colloidal platinum, Int. J. Hydro. Energy, 29, $39-42$.

FÁBREGAS, J.; LLOVO, J. \& MUÑOZ, A. Hemagglutinins in red seaweeds. Botanica Marina, 28(12):517-520, 1985.

HOICZYK, E. 2000, Gliding motility in cyanobacteria: observations and possible explanations, Arch. Microbiol., 174, 11-7.

HORI, K.; MIYAZAWA, K.\& Ito, K. Hemagglutinins in marine algae. Bulletin Japanese Society of Scientific Fisheries, 47(6):793-798, 1981.

LIMA, H.C.; COSTA, F.H.F.; SAMPAIO, A.H.; NEVES, S.A.; BENEVIDES, N.M.B.; TEIXEIRA, D.I.A; ROGERS, D.J.; FREITAS, A.L.P. Induction and inhibition of human lymphocyte transformation by the lectin from the red marine algae Amansia multifida. Journal Applied of Phycology, v. 10, p. 153-162, 1998.

LOSEVA, L.P. and Dardynskaya, I.V. 1993, Spirulina natural sorbent of radionucleides, 6th International Monographs, University of California Press: Berkeley and Los Angels, pp. 30731.

MUÑOZ, A.; LLOVO, J. \& FABREGAS, J. Hemaglutininas de algas verdes. Acta Científica Compostelana, 22:873- 878, 1985.

NEVES, S.A.; BARU, Y.M.D.; FREITAS, A.L.P.; BARREIRA, M.C.R. Neutrophil migration induced in vivo and vitro by marine algae lectins. Inflammation Research, v. 50, p. 486-490, 2001 
SAMPAIO, A.H; AINOUZ, I.L; FREITAS, A.L.P; BENEVIDES, N.M.B. Hemagutininas de Algas Marinhas. R. Bras. Fisiol. Veg., 5(2):171-177, 1993.

SCHOSSER, U.G. Sammlung von Algenkulturen. Ber. Dtsch. Bot. Ges. v.95, p.181-276, 1982.

TOMASELLI L, Maria Rosa P, Mario RT. On the cor-rect use of the Spirulina designation. Algol Stud 1996; 83:539-548.

VAN TUERENHOUT, D. 2005, The Aztecs: New Perspectives, ABC-CLIO 